\title{
Do Chronic Fatigue Syndrome and Atherosclerosis Share Common Molecular Risk Factors?*
}

\author{
Bianca V.A. Eder Florian Überall \\ Nutritional Biochemistry and Nutrigenomics, Division of Medical Biochemistry, Biocenter Innsbruck, Innsbruck Medical School, Austria
}

\section{Keywords}

Atherosclerosis · Chronic fatigue syndrome - Oxidative stress .

Psychosocial and physical stress

\section{Summary}

In the past 50 years, numerous studies have identified novel risk factors for atherosclerosis. Chronic fatigue syndrome (CFS), an illness characterized by lasting disabling fatigue and referred to as a 20th century phenomenon, is highly prevalent, and the number of people affected is increasing. Although the influence of physical and psychological stress factors on atherosclerosis has been recognized, the role of psychosocial risk factors has received far less attention in cardiac practice and in the research of atherosclerosis. Despite the fact that these represent highly relevant aspects of this disease, their potential role in promoting CFS has not been systematically explored. In this context, certain questions arise that need to be answered. Studies investigating oxidative stress (OS) in CFS report (i) significantly increased low-density lipoprotein (LDL) oxidation, (ii) significantly reduced plasma concentrations of high-density lipoprotein and vitamin E, (iii) a significantly reduced lag phase for ex vivo oxidized LDL, (iv) increased augmentation index normalized for a heart rate of 75 beats/ min (Alx@75), and (v) gene expression alterations of ATP-binding cassette transporters (e.g. $A B C D$ 4) and the integral peroxisomal membrane protein PEX 16. Evidence for OS in patients with this syndrome has been strengthened by studies demonstrating increased C-reactive protein levels, high blood pressure, and increased numbers of erythrocytes in a stomatocytic form. Furthermore, there are reports of cardiovascular impairment in many CFS patients, with underlying pathomechanisms such as autonomic dysfunction, attenuated heart rate and blood pressure regulation, increased vasomotor tone, and loss of heart rate variability. These findings suggest that CFS itself is a chronic state of inflammation lasting over long periods of time from 3 to

*Parts of this article are based on the diploma thesis of Bianca V.A. Eder for the University of Innsbruck, Austria, and have been updated as well as expanded accordingly by the authors.
9 years. The results of present studies suggest that there are individual risk factors, such as physical and/or psychological stress, for CFS and that it is a molecular risk factor for atherosclerosis. The presence of reactive oxygen species and chronic inflammation in atherosclerosis and CFS indicates that the two diseases may have common underlying molecular mechanisms.

\section{Schlüsselwörter}

Atherosklerose - Chronisches Müdigkeitssyndrom • Oxidativer Stress . Psychosozialer und physischer Stress

\section{Zusammenfassung}

Verbinden das Chronische Müdigkeitssyndrom und die Atherosklerose gemeinsame molekulare Risikofaktoren?

Während der letzten 50 Jahre wurden in zahlreichen Studien neue Risikofaktoren für Atherosklerose identifiziert. Das Chronische Müdigkeitssyndrom (CFS), eine Krankheit mit dem Hauptsymptom einer andauernden, kräftezehrenden und beeinträchtigenden Erschöpfung sowie hoher Signifikanz und Prävalenz, wurde als Phänomen des 20. Jahrhunderts bezeichnet. Obwohl die Beeinflussung von Atherosklerose durch psychischen und physischen Stress nachweislich existiert, wurde psychosozialen Risikofaktoren bisher wenig Aufmerksamkeit geschenkt. Wissenschaftlich fundierte Erkenntnisse weisen bereits darauf hin, dass dies den bedeutendsten und wesentlichsten Aspekt darstellt, der bisher im medizinischen und wissenschaftlichen Bereich nicht vollständig erforscht worden ist. Diese Tatsache wirft weitere Fragen auf. Diverse Studien, die oxidativen Stress (OS) in Patienten mit CFS untersuchten, berichteten folgende Fakten: (i) signifikant erhöhte Oxidation von Low-Density-Lipoproteinen (LDLs), (ii) signifikant reduzierte Plasmakonzentrationen von High-Density-Lipoproteinen und Vitamin E, (iii) signifikant erniedrigte Lag Phase des LDL-Spiegels, (iv) erhöhter Augmentationsindex auf die Herzfrequenz 75 berechnet (Alx@75) und (v) Änderung in der Genexpression von ABC-Bindungskassetten-Proteinen (z.B. ABCD 4) und dem peroxisomalen Membranprotein PEX 16. Der Nachweis des OS in Patienten, die von diesem

\section{KARGER \\ Fax +497614520714 Information@Karger.de} www.karger.com
A. Univ.-Prof. Mag. Dr. Florian Überall, $\mathrm{PhD}$

Nutritional Biochemistry and Nutrigenomics, Division of Medical Biochemistry Biocenter Innsbruck, Innsbruck Medical School

Fritz-Pregl-Strasse 3, 6020 Innsbruck, Austria

Tel. +43 512 9003-70120, Fax -73130

florian.ueberall@i-med.ac.at 
Syndrom betroffen sind, wurde durch Studien, die erhöhte C-reaktive Protein-Spiegel und erhöhte Blutdruckwerte sowie eine Erhöhung von Erythrozyten mit stomatozytärer Form dokumentierten, bestärkt. Darüber hinaus zeigten fundierte Daten eine tatsächliche kardiovaskuläre Beeinträchtigung von vielen CFS-Patienten durch Pathomechanismen wie autonome Dysfunktion, abgeschwächte Herzfrequenz- und Blutdruckregulation, gesteigerten vasomotorischen Tonus und Abnahme der Herzfrequenzvariabilität. Das CFS selbst ist ein chronischer Entzündungszustand, der über lange Zeiträume (Krankheitsdauer 3-9 Jahre) besteht. Die Resultate der durchgeführten Untersuchungen erlauben die Schlussfolgerung, dass das CFS durch individuelle Risikofaktoren, wie extensiven physischen und/oder psychischen Stress, verursacht wird und dass es einen molekularen Risikofaktor für Atherosklerose darstellt. Die Präsenz von reaktiven Sauerstoffspezies und chronischen Entzündungen, die die Atherosklerose und das CFS begleiten, lassen gemeinsame molekulare Mechanismen erkennen.

\section{Mots-clés}

Athérosclérose - Syndrome de fatigue chronique - Stress oxydatif . Stress psychosocial et physique

\section{Résumé}

Le syndrome de fatigue chronique et l'athérosclérose partagent-ils des facteurs de risque moléculaires communs?

Au cours de ces 50 dernières années, de nombreuses études ont identifié de nouveaux facteurs de risque de l'athérosclérose. Qualifié de phénomène du XXe siècle, le syndrome de fatigue chronique (SFC) est une maladie dont le symptôme principal est un épuisement persistant et invalidant. Bien que l'influence du stress psychique et physique sur l'athérosclérose a été prouvée, peu d'attention a, jusqu'à présent, été portée aux facteurs de risque psychosociaux. Des connaissances scientifiques indiquent déjà que de tels facteurs représentent l'aspect le plus important et fondamental de cette maladie, aspect n'ayant pas encore fait l'objet de recherches systématiques dans le domaine médical et scientifique. Ceci soulève d'autres questions. Différentes études portant sur le stress oxydatif (SO) chez des patients atteints de SFC ont rapportés les faits suivants: (i) une augmentation significative de l'oxydation des lipoprotéines basse densité (LDL, low-density lipoproteins); (ii) une diminution significative des concentrations plasmatiques de lipoprotéines haute densité et de vitamine E; (iii) une diminution significative de la phase de latence (lag phase) taux de LDL; (iv) une élévation de l'index d'augmentation calculé pour une fréquence cardiaque de 75 battements/min (Alx@75); et (v) une modification de l'expression génétique des cassettes de liaison $A B C$ (p. ex. $A B C D 4)$ et de la protéine membranaire péroxisomale PEX 16. La démonstration du SO chez les patients atteints de SCF a été corroborée par des études ayant rapporté une augmentation du taux de protéine réactive $C$ et une élévation de la pression artérielle, tout comme une augmentation d'érythrocytes de forme stomatocytaire. En outre, des données solides ont montré, chez de nombreux patients SFC, une atteinte cardiovasculaire effective liée à des mécanismes pathologiques tels que: dysfonction autonome, affaiblissement de la régulation du rythme cardiaque et de la pression artérielle, augmentation du tonus vasomoteur et réduction de la variabilité du rythme cardiaque. Le SFC est, par définition, un état infectieux chronique qui se maintient pendant de longues périodes (durée de la maladie: 3 à 9 ans). Les résultats des études menées permettent de conclure que le SFC trouve son origine dans des facteurs de risque individuels comme un stress physique et/ou psychique important et que ce syndrome représente un facteur de risque moléculaire de l'athérosclérose. La présence d'espèces réactives d'oxygène et d'infections chroniques accompagnant l'athérosclérose et le SFC révèle des mécanismes moléculaires communs.

\section{Introduction}

According to World Health Organization (WHO) statistics, cardiovascular disease (CVD) ranks first in mortality globally [1]. CVD includes coronary heart disease (e.g. myocardial infarction), cerebrovascular disease (e.g. stroke), hypertension, heart failure, peripheral artery disease (e.g. gangrene), rheumatic heart disease, and congenital heart disease [2]. The underlying pathology for CVD is atherosclerosis [3]. 'Unexplained medical symptoms' or 'subjective health complaints' are very common in the general population, with the most common complaints being musculoskeletal pain, gastrointestinal complaints, and 'pseudoneurology' (tiredness, sleep problems, fatigue, and mood changes) [4]. Illnesses found amongst these diagnoses are burnout, epidemic fatigue, multiple chemical sensitivity, chronic musculoskeletal pain, chronic low back pain, fibromyalgia, and chronic fatigue syndrome (CFS) [4]. CFS has a wide prevalence in the general population. Some individuals with CFS are severely enough impaired to require care and assistance [4]. Thus, both atherosclerosis and CFS affect general populations worldwide, and it has increasingly become a global health and economic issue to combat these illnesses. There is evidence linking stress, of both physical and psychological nature, to CFS and atherosclerosis; however, few investigations examining the connection between CFS and atherosclerosis have been undertaken up to now. The aim of this paper is to summarize what is known about these two diseases and to draw attention to a possible common underlying molecular mechanism.

\section{Chronic Fatigue Syndrome}

CFS, also referred to as immune dysfunction syndrome and myalgic encephalomyelitis, describes a range of complaints as well as a heterogenic group of symptoms and is characterized by a persistent and unexplained fatigue, not alleviated by rest, which results in substantial reduction in previous levels of occupational, educational, social, and personal activities. CFS has a high prevalence as it affects 
Table 1. Case definition of CFS, 1994 (modified after [141])

Characterized by persistent or relapsing unexplained chronic fatigue

Fatigue lasts for at least 6 months

Fatigue is of new or definite onset

Fatigue is not the result of an organic disease or of continuing exertion

Fatigue is not alleviated by rest

Fatigue results in a substantial reduction in previous occupational, educational, social, and personal activities

Four or more of the following symptoms concurrently present

for at least 6 months:

Impaired memory or concentration

Sore throat

Tender cervical or axillary lymph nodes

Muscle pain

Multi-joint pain

New headaches

Unrefreshing sleep

Postexertional malaise lasting more than $24 \mathrm{~h}$

Exclusion criteria

Medical condition explaining fatigue

Major depressive disorder (psychotic features) or bipolar disorder

Schizophrenia, dementia, or delusional disorder

Anorexia nervosa, bulimia nervosa

Alcohol or substance abuse

Severe obesity

approximately 500 women and 250 men or even more from all age groups (including children) per 100,000 individuals [5], and there is evidence that the numbers are rising [6]. Referred to as a 20th century illness [7], the mean age of onset of CFS is between 29 and 35 years [7]. Although the prevalence in different geographic locations and in diverse ethnic groups was found to be similar [8], rates show that members of minority groups and individuals with a lower educational and occupational status are more affected [5, 9]. Additionally, CFS is found in significant numbers among hospital staff members [10]. It is evident that both atherosclerosis and CFS affect general populations worldwide and it has increasingly become a global health and economic issue to combat these illnesses.

There are conflicting reports about the prevalence of CFS among children and adolescents. While CFS prevalence is given as lower among children and adolescents than among adults in some studies [11-13], according to another study, stress disorders generally seem to be rapidly on the rise, especially in children [14]. Since CFS can be regarded as a form of stress disorder, DeMeirleir et al. [6] have suggested that the prevalence of CFS is increasing.

CFS can affect virtually every major system in the body, ranging from neurological, immunological, hormonal, gastro-intestinal, musculoskeletal to psychological symptoms [15]. The symptoms vary widely between patients, and most show concomitant symptoms. The most commonly accepted scientific case definition is the 1994 definition of the US Center for Disease Control and Prevention (CDC) (table 1) [16].
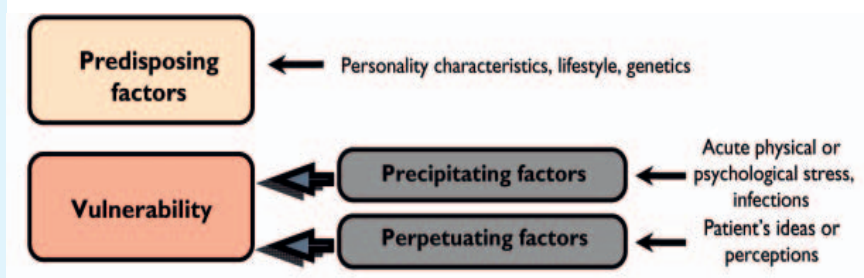

Chronic Fatigue Syndrome (CFS)

Fig. 1. Aetiology of CFS syndrome, consisting of predisposing, precipitating, and perpetuating factors.

As affected individuals often report an acute onset of symptoms after an illness of an infectious nature [17-19], it has been hypothesized that infectious agents are the cause of CFS, but the results from different studies remain controversial and conflicting [20] and the crucial microorganism, if any, has not been identified [21]. However, an association between psychosocial stress and the incidence of infections is now established [22].

A model which helps to understand the complex aetiology of this syndrome is one which distinguishes between predisposing, precipitating, and perpetuating factors (fig. 1). So far it is understood that one or more factors in each of these categories are necessary, though insufficient for an individual to develop CFS [7].

- Predisposing factors: Personality and lifestyle have an impact on the vulnerability to CFS [7], with certain personality characteristics being special risk factors [23]. Gender is clearly implicated, as women have a tendency to develop CFS almost twice as often as men. Although it has been suggested that a familial predisposition might exist, no genetic abnormalities have been found to date [24-26]. Smith et al. [27] found an association of CFS with HLA DQA $1^{\star} 01$, but this needs to be investigated further.

- Precipitating factors: Acute physical or psychological stress is presumed to trigger the onset of CFS [19]. 75\% of CFS patients have reported that their illness was triggered by infections such as a cold, flu-like illness, or infectious mononucleosis $[19,28]$. Several studies have investigated whether psychological stress is the trigger for this disorder. In this context, it has been noted that serious life events, such as the loss of a loved one or a job, and the struggle with dilemmas can precipitate CFS [21, 29].

- Perpetuating factors: Once CFS has developed, several maintenance factors hinder the recovery, and thus the average patient suffers from 3 to 9 years from this disorder. Amongst others, the patient's ideas or perceptions about their complaints are conducive to a perpetuation of the illness. Additionally, psychological processes 
involving avoidance strategies can be relevant. In a twin study of monozygotic twins, discordant for CFS, it has been found that the twin affected by CFS had been using more avoidance strategies than the non-fatigued twin [30].

Cognition and behavioural factors such as the strong belief of having no control of the physical symptoms, the fixation on a somatic cause of the disorder, and attention focused on bodily symptoms have a direct effect on the severity of fatigue and physical, mental, and social impairment and therewith on the persistence of CFS [31-35]. Equally, sleep [36-38], rest, and the resulting recreation are influenced by the patient's concept of their illness and especially by catastrophic beliefs [39].

However, other perpetuating factors must not be underestimated. These range from a lack of social support [40] to a reinforcement of illness behaviour by the patient's environment including the family and partner [41-43]; even the manner in which practitioners deal with CFS and affected patients can result in communication problems $[44,45]$. A chronic illness can provide benefits such as increased attention and care from loved ones but also a lack of engagement and even of financial benefits, all of which might contribute to the perpetuation of the illness $[46,47]$.

As the origin of the disease has not been identified, there continues to be a lack of information regarding its pathophysiology. There is broad consensus regarding a complex and multifactorial aetiology and that practically all biological systems, such as the central nervous system, the immune system, the hormonal regulation system, and the cardiovascular system, are involved [15, 48, 49].

Studies investigating the neuroendocrinology of CFS patients have reported that although corticotropin concentrations were high, cortisol was lower than normal [7]. Additionally, the serotonergic system was upregulated [7].

The interplay of these systems seems to be of particular relevance. Psychological and behavioural aspects such as stress, which are involved in the precipitation and perpetuation of the disease $[21,50]$, influence the endocrine system which interplays with the immune system, eventually causing dysfunction of the immune system [51], which in turn leads to certain neuroendocrinal and immune mechanisms and therewith to symptoms of CFS [52-54]. Mounting evidence suggests that the neuroendocrine dysregulations are acquired [55], and not congenital.

The evidence that oxidative stress (OS) and particularly lipid peroxidation plays a key role in the disease process, pathology, and also symptomatology is accumulating [5658]. Several studies have reported an increased OS in CFS patients, both in plasma and in muscle (oxidative damage to DNA and lipids in muscle specimens) [59-61]. OS can be defined as an imbalance between prooxidative versus antioxidative systems in favour of prooxidation $[48,57]$. OS includes a number of chemical reactions involved in the production of free radicals and other reactive molecules that are potentially able to induce cellular injury [48]. Since lipid peroxidation indirectly reflects the presence of free radicals, which are known to take part in pain production in several chronic pain conditions $[62,63]$, free radicals appear to be a major contributing cause to hyperalgesia and symptomatology of CFS patients.

\section{Atherosclerosis}

Atherosclerosis is the main pathology underlying CVDs [3]. The risk factors for atherosclerosis are dyslipidaemia, elevated blood pressure (hypertension), and other factors such as tobacco use, elevated blood glucose (diabetes mellitus), unhealthy diet, and physical inactivity (both leading to obesity), psychological stress, and genetic predispositions etc. $[3,64]$. Furthermore, high homocysteine levels (HCY blood serum levels between 3.3-15.3 $\mu \mathrm{mol} / \mathrm{l}$ ) and low antioxidative capacities are associated with the process of atherosclerosis [64, 65].

Atherosclerosis is defined as a chronic inflammatory disease resulting from the interplay of modified lipoproteins, monocyte-derived macrophages, T-cells, and cellular elements of the arterial wall. It is characterized by a degenerative change of arterial blood vessels and takes place mainly in the intima. In this arterial remodelling, the accumulation of fatty substances, cell proliferation, reactive inflammation, necrosis, proliferation of fibrous elements, and calcification lead to wall thickening and loss of elasticity of the vessel $[64,66]$. In the presence of risk factors such as fluid shear stress (e.g. through high blood pressure), progression of the lesion occurs and the atherosclerotic plaque is formed. This eventually leads to the stenosis of the lumen which causes constriction of blood vessels [64]. Atherosclerosis eventually results in acute cardiovascular events such as myocardial infarction, stroke through thrombosis, or plaque rupture $[67,68]$. Acute events are thought to depend on the plaques' composition which determines their vulnerability. Plaque ruptures mainly manifest at plaque edges, which are a site of increased foam cell concentration, and in lesions with thin fibrous caps and large necrotic cores. Additionally, vulnerable plaques consist of an increased number of inflammatory cells [64]. These circumstances suggest that other factors enhancing inflammation additionally influence thrombosis. The incidence of myocardial infarction and stroke increases during acute infections [64]. The formation of the necrotic core is quantitatively influenced by apoptosis [69]. Programmed cell death in the intima is the result of cellcell interactions and of the local cytokine environment including death receptors, proto-oncogenes, and tumour suppressor genes. However, oxidized low-density lipo- 
protein (oxLDL) seems to advance apoptosis and necrosis in lesions [70].

Apoptosis of macrophages and smooth muscle cells may be important not only in determining the ability of lesions to undergo regression but may also influence plaque stability [71]. Another factor are matrix metalloproteinases, which are secreted by dying macrophages that have been found in the areas of plaque rupture and that influence plaque stability by degrading extracellular matrix proteins $[72,73]$.

In summary, the progression of atherogenesis and its acute clinical events appears to be dependent directly or indirectly on the concentration of foam cells (macrophages/monocytes) and oxLDL. Inflammation seems to be the major factor here, which, among others, is the result of ongoing fluid shear stress and OS, with lipid components playing the role of an additional vehicle in the oxidation process rather than being the culprit agent themselves.

LDL undergoes specific modifications in the vessel wall such as oxidation, lipolysis, proteolysis, and aggregation which lead to inflammation and additionally, in the interaction with monocytes/macrophages, to the formation of foam cells $[64,74]$. The impact of oxLDL depends strongly on the extent of modification, ranging from 'minimal' oxLDL to extensive oxidation [71].

The accumulation of oxLDL in the intima of arteries causes the overlying endothelium to express adhesion molecules and growth factors such as macrophage colonystimulating factor (M-CSF) [64]. Additionally, vascular cell adhesion molecule (VCAM-1) [75], E selectin and P selectin [76], and intracellular adhesion molecule (ICAM-1) [77] have been suggested to be a response to this inflammatory stimulus. This can be seen as the triggering event to recruit monocytes and lymphocytes (T-cells), but not neutrophils, to the site [64]. Although this process initially represents a protective function by eliminating cytotoxic and proinflammatory oxLDL and apoptotic cells, the progression of foam cell formation in the arterial wall and its activation of immune responses ultimately results in atherosclerotic lesions $[64,71]$. In this sense, atherogenesis can be seen as a 'response to injury' [64].

Interactions between macrophage foam cells, Th1 cells, and Th2 cells are believed to establish a chronic inflammatory process [71]. Both lymphocytes and macrophages release cytokines, such as Il-4, Il-10, Il-13, and IFN $\gamma$, which have pro- as well as antiatherogenic effects on cell components of blood vessel walls [71]. Some of the cytokines mentioned above provoke the formation of a fibrous plaque through the migration of smooth muscle cells from the artery's media into the intima and their proliferation and synthesis of extracellular matrix protein [71]. As a result, further inflammatory molecules are secreted, including TNF $\alpha$, IL-6, and monocyte chemotactic protein 1 (MCP-1) [71].

However, several other factors, such as haemodynamic forces (for example hypertension), homocysteine levels, sex hormones, infection [64,78], and diabetes through its advanced glycation end products, need to be considered as inflammation modulators [79] and therewith as contributors to the development of this disease.

Another effect of oxLDL is the inhibition of nitric oxide production [64]. As a result, there is a deficiency of the antiatherogenic components of the chemical mediator nitric oxide which are responsible for vasodilatation, causing further vessel constriction.

While environmental risk factors associated with atherosclerosis are better known, with the exception of errors of lipid metabolism, the contribution of genetic
Fig. 2. Oxidative stress as a central mediator of atherosclerosis (modified after [142]). ACE = Angiotensin-converting enzyme; VCAM = vascular cell adhesion molecule; ICAM = intracellular adhesion molecule.

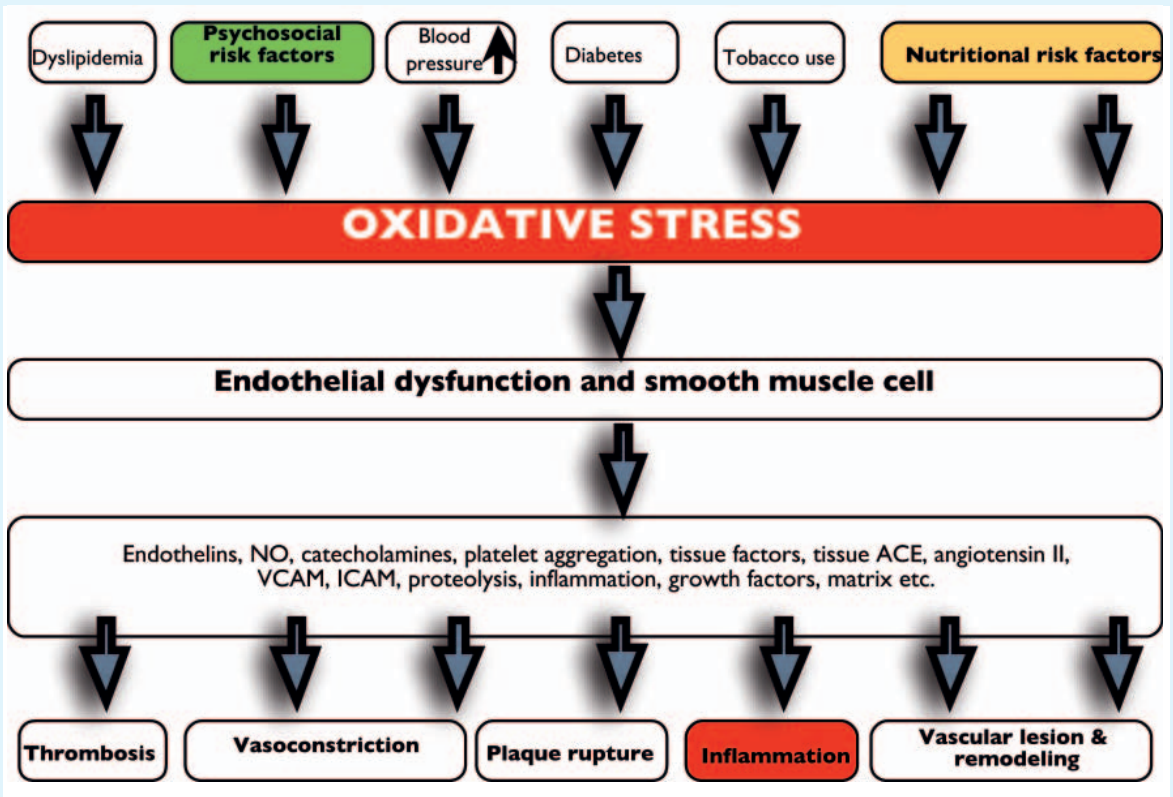


factors with a heritability of $50 \%$ to this aeteologically complex disease is less well understood. Oxidative processes in the artery wall may be proatherogenic by promoting accumulation of cholesterol esters in the macrophages (via oxidization of LDL) or antiatherogenic, resulting from second messenger formation or activation of nuclear transcription factors which suppress inflammation, and thus prevent atherosclerosis. Which of these mechanisms is predominant as well as the role of the genetic regulation and molecular pathway of enzymes involved in oxidation processes in the artery wall is not yet clear.

Genes that predispose to hypertension and diabetes mellitus, control arterial diameter, reactivity, and branching angles, affect platelet adhesiveness, thrombosis, and fibrinolysis, and regulate endothelial and smooth muscle function can all be considered as candidate genes. Many candidate genes in the common forms of atherosclerosis have been investigated but few have been confirmed; variations of hepatic lipase and HDL levels, apolipoprotein E (apoE) and LDL levels, apoCIII/apoAV and triglyceride levels, and paraoxonase 1 and myocardial infarction offer some understanding of the genetic susceptibility to atherosclerosis in humans.

It is generally accepted that atherogenesis consists of a caregiving interplay of nutritional aspects, amongst others resulting in raised LDL levels, and the underlying causes of shear stress and subsequently OS. This leads to the oxidation and accumulation of LDL, the continuous recruitment of monocytes/macrophages and lymphocytes, and eventually to a chronic inflammatory state, which can ultimately progress to the atherosclerotic plaque, and through rupture to an acute cardiovascular event (fig. 2).

\section{Discussion}

Psychosocial factors that promote atherosclerosis and adverse cardiac events include emotional factors and chronic stressors: the former comprise affective disorders such as major depression and anxiety disorders as well as hostility and anger, and the latter include factors such as low social support, low socioeconomic status (SES), and work/marital/caregiver stress [80, 81]. Furthermore, several studies have not only reported a relationship between hostility or anger and measurements of subclinical atherosclerosis [82-85] but additionally documented a link between the progression of atherosclerosis and hostility. The latter was shown during serial coronary angiography [86].

Chronic stressors, specifically the lack of social support, have an impact on cardiac death and all-cause mortality [81]. Low SES, characteristically a low occupational and social status, low economic resources, and low educational attainment, is very often accompanied by poorer health habits and increased risk factors for atherosclerosis and cardiac disease. Low SES is furthermore characterized by financial hardship, poorer housing conditions, and increased levels of chronic stress [87]. Chronic stress is frequently accompanied by a dysfunction of the hypothalamic-pituitary-adrenal (HPA) axis and falling SES levels are accompanied by increased HPA dysfunction [80]. As far as the role of caregiving strain in the context of atherosclerosis is concerned, some studies report an increased risk for experiencing a cardiac event [88], while others report the psychological benefit of highly meaningful and altruistic experiences [89]. It would appear that the effects of caregiving are dependent on the kind and on the meaning of the performed activities.

There is a strong overlap between chronic stress and emotional factors, and life situations capable of triggering chronic negative emotional responses can favour the development of heart disease [80].

Thus it can be suggested that life circumstances such as physical and psychological stress and serious life events which lead to the outbreak of CFS, and the ongoing stress caused by the persistence of the disease symptoms over years once CFS has been acquired, can promote atherosclerosis. This needs to be explored on a molecular basis.

There are several endogenous and exogenous factors which account for an increase of reactive oxygen species (ROS) concentrations in humans (table 2) [90]. The production and elimination of ROS takes place along many biochemical pathways. The following mechanisms work as antioxidants, defending the body against the attack of ROS:

- Various low-molecular-weight compounds contained in the diet, such as vitamin C, vitamin E, and carotenoids [90].

- Intrinsic molecules such as glutathione [91], albumin [92], bilirubin [93], and uric acid [94].

- Enzymes that specifically degrade potential ROS precursors, such as glutathione-reductase and $\mathrm{NADPH} / \mathrm{H}^{+}$, superoxide-dismutase and glutathione-peroxidase, and catalase [91].

The gold standard to measure elevated levels of in vivo OS is to gauge the level of isoprostanes [48].

OS occurs if the antioxidant defence mechanisms are overwhelmed by the production of ROS. The cell membrane is damaged [91], and additionally, the cell becomes more vulnerable to the effect of other prooxidant factors or toxic agents [90]. Oxidative actions of ROS have a cumulative effect on the central nervous system [95]. Different relative risk factors affect each other and potentiate the absolute risk of atherosclerosis [96].

Psychological and physical stress has been found to have an impact on antioxidant defences. Various types of stress are reported to hamper antioxidant defence systems in the brain [95]. Interference with the sensitive antioxidant 
homoeostasis as well as an increase of ROS can promote oxidative damage to DNA, proteins, and lipids [97-99]. Already in 1985 it was reported that a high level of psychological stress was associated with dysfunctions on the molecular level [100]. Another study showed that psychological stress additionally inhibits radiation-induced apoptosis in human peripheral blood leukocytes [101]. These findings implicate that oxidative damage abides during psychosocial stress and continuously increases the probability of developing pathology.

Biological stress interferes with host defence systems and additionally plays a decisive role in the development of various disease states [102]. As a significant amount of neutralizing antioxidants is needed for the prevention of damage to the immune cells in this process, it has been suggested that the systemic immunocompetence is affected by biological stress [96]. Furthermore, it has been found that there is a fundamental connection between free radical accumulation and the evolution of inflammation and inflammation-related responses [96]. Chronic psychosocial stress promoting reactive oxygen species, which continuously causes inflammatory responses, can thus be considered as a chronic inflammatory state.

As mentioned above, OS seems to play a decisive role in CFS, and various studies have documented an increased OS in CFS patients.

Statistically significantly increased levels of 8-Iso-prostaglandin $\mathrm{F}_{2 \alpha}$, a member of the $\mathrm{F}_{2}$-isoprostane family and a potent platelet activator, vasoconstrictor, and oxLDL in CFS, have been reported $[103,104]$. Additionally, significantly lower levels of HDL in CFS and an association between raised levels of isoprostanes and CFS symptoms have also been observed [48]. This biochemical profile, including the gold standard detection of OS, matches the risk factors of atherosclerosis and CVD [105]. In this context, it has been suggested that not secondary effects of CVD risk factors were accountable for the prooxidant state found in CFS patients but that it is due to the consequences of CFS as an illness itself [48]. This evidence was reproduced in a recent study performed in 2008 [49]. Additionally, lipid assets, hemochrome and inflammatory markers were found not to vary among CFS and controls so that OS was unlikely to occur due to dyslipidaemia or inflammatory cells [57].

It has been postulated that CFS is proinflammatory [48], and considering the duration of predisposing and precipitating factors as well as the length of the illness itself, CFS can be regarded as a chronic inflammatory state.

In 2003, Vecchiet et al. [57] explored the LDL oxidation in CFS as the susceptibility of LDL to undergo lipid peroxidation and as the LDL lipid peroxide content measured via fluorometrically detected thiobarbituric acid reactive substances (TBARS) by standardized methodology [106108]. This survey found that TBARS were significantly
Table 2. Oxidative stress factors (modified after [90])

\begin{tabular}{l}
\hline Endogenous factors \\
Physical exercise/sedentary lifestyle \\
Psychological stress \\
Inflammation (transient infection/chronic disease) \\
Cancer \\
Ischemia/reperfusion \\
Cell death \\
\hline Exogenous factors \\
Food consumption \\
Protein and/or lipid rich diet \\
Prooxidants (xenobiotics ${ }^{\mathrm{a}}$ ) \\
Antioxidants (low dietary intake) \\
Beverages (alcohol, coffee) \\
Airborne pollutants \\
Cigarette smoke \\
Air pollution ( $\mathrm{SO}_{2}, \mathrm{NO}_{2}, \mathrm{O}_{3}$, hydrocarbons) \\
Occupational (transition metals, asbestos, paraquat) \\
Medical drugs \\
Anticancer drugs \\
Psoralens \\
Radiation \\
Ionizing radion \\
Ultraviolet radion \\
Microwaves \\
Skin absorbants \\
Insecticides (eldrin, $\mathrm{DDT}_{\text {, lindane) }}$ \\
Psoralens (celery pickers) \\
Drugs (lindane, psoralen derivates) \\
\hline${ }^{\text {aXX }}$ Xenobiotics may also be inhaled or absorbed through the skin. \\
\end{tabular}

Xenobiotics may also be inhaled or absorbed through the skin.

higher in CFS whereas the plasma and LDL concentrations of lag phase, i.e. the time necessary to initiate peroxidation which precedes the formation of conjugated dienes, and Vitamin E (Vit E) were significantly reduced. Thus, Vecchiet et al. [57] found not only more data supporting previous findings of circulating OS in CFS patients but additionally stated that specifically lag phase and Vit E in plasma were significantly correlated to fatigue and degree of muscle hyperalgesia. The latter reflects clearly the high expression of OS in skeletal muscles, due to their poor antioxidant defences [109].

Amongst others, another study found high blood pressure (BP), lower HDL, elevated C-reactive protein (CRP) levels, and significantly increased augmentation index normalized for a heart rate (HR) of 75 beats/min (AIx@75) - a composite measure of arterial stiffness and wave reflection - in patients with CFS [49]. In this analysis, AIx@75 was significantly associated with CRP and isoprostane levels. As AIx is an indicator for arterial wall stiffness, it was shown in several studies to be an important determinant of cardiovascular risk and its outcome [110116]. Thus, in CFS patients, a combination of increased arterial wave reflection, inflammation, and OS can lead to unfavourable haemodynamics and an increased risk of a future cardiovascular event [49]. 
CRP levels indicate a chronic, low-grade, subclinical inflammation and serve as a potential endorsing marker in the general prediction of cardiovascular risk [117, 118].

The findings of OS as a disease mechanism in CFS have also been detected in the gene expression of peripheral blood mononuclear cells. In this regard, a study recently documented a significant gene alteration of ABCD 4 and PEX 16, both located in the peroxisomal membrane, which suggests enhanced defence to OS in CFS [119].

Several studies have shown that erythrocytes are part of the body's free radical scavenger system [120-125], besides their other function as vehicles for gas exchange. In the role as scavengers of free radicals, the red blood cells become damaged through oxidation, which decreases endogenous reducing substances [126]. Research of illnesses which are associated with significant free radical formation, such as rheumatoid arthritis, gives evidence of erythrocytic oxidation [126]. The damage in erythrocytes through oxidation consequently has a damaging impact on the erythrocyte shape and increases their rigidity through peroxidation and oxidation of labile groups in the proteins of the cytoskeleton [127]. It has previously been noted that CFS patients show significantly different erythrocyte profiles compared to controls [128]. Statistically significant increases in 2,3-diphosphoglyceric acid (2,3-DPG), methemoglobin (metHb), and malondialdehyde (MDA), all of which are parameters for erythrocyte oxidative damage, have been reported [127].2,3-DPG is an important indicator for the deformability of red blood cells [129] and increased 2,3-DPG is associated with increased fragility and decreased deformability of these cells [130].

As 2,3-DPG has the role of regulating the haemoglobin oxygen affinity [131, 132], its increased levels indicate a compensational mechanism for reduced oxygen delivery to tissues [127]. The significantly increased levels of met $\mathrm{Hb}$ are an indicator of oxidative damage to the haemoglobin molecule [127]. MDA is a product of lipid peroxidation due to OS [127]. Additionally, this study measured the erythrocyte forms in CFS patients as well as the healthy control group and found that CFS patients had significantly more stomatocytes in their blood than the control group. Increased erythrocyte antioxidant activity is thus believed to be correlated with the presence of stomatocytes [127]. Stomatocytes can, among others, be induced through hydrogen peroxide [133] and hydrostatic pressure [134]. It has been suggested that erythrocytes are no longer flexible enough without their usual biconcave form to change their shape as required for microcirculation [135]. The consequence is a blood flow decrease on the microcirculatory level, resulting in reduced general oxygen supply and an accumulation of by-products of cellular respiration [136].

These pathophysiological mechanisms can cause an oxygen deficit to muscles and postexertional fatigue and exercise intolerability of CFS patients. Additionally, this could explain the symptomatology of multiple organ systems of CFS patients.

In summary, considering the CFS aetiology of extreme physical or mental stress, the effect of stress on molecules in the form of OS, which has been detected in patients suffering from CFS, and the well-explored impact OS has on the endothelium, on molecules such as LDL and erythrocytes, and consequently on atherogenesis, CFS can be regarded as a risk factor for atherosclerosis.

As noted, chronic stress and low SES are often associated with a dysfunction of the HPA axis. Previous studies on the HPA axis involvement were heterogeneous, very likely due to heterogeneity of patient populations, methods, and study design. A recent study reported that CFS patients responded with a decrease of stimulated cytokine production shortly after stress, whereas it increased in the healthy individuals of the control group [137]. Additionally, the fatigue scores in CFS patients were significantly interrelated with integrated levels of lipopolysaccharideinduced cytokines.

Furthermore, autonomic dysfunction [138], attenuated HR and BP regulation [139], and increased vasomotor tone and loss of beat-to-beat HR control [140] are thought to underlie cardiovascular impairment in many CFS patients. Besides the molecular mechanisms of OS and its consequences, this shows that there are additional pathomechanisms at work in CFS which lead to an essential clinical compromise of the cardiovascular system of many CFS patients.

\section{Conclusion and Implications for Practitioners}

Large parts of the global population choose to live unhealthy lifestyles, while others are living in a daily struggle for food, clean water supplies, and overall acceptable living conditions. Additionally, people generally live more stressful and sedentary lives nowadays [90]. These circumstances can be seen in the reflection of the global prevalence of atherosclerosis in the form of CVD. Its impact on society is already now fundamental, with the mortality rates due to this illness ranking on first place globally and with global deaths predicted to increase drastically. Atherosclerosis is a process lasting over decades and requiring lifetime preventive measures.

At the same time the global CFS prevalence is high, with rising numbers, and it can be considered a 20th century illness affecting especially members of minority groups as well as people with lower educational and occupational status, with a very high vulnerability among women and hospital staff members. Prevalence of CFS in children has been found to be significant. It has increasingly become a global health and economic issue for all nations to combat these illnesses. 
In the past 50 years, numerous epidemiologic studies have been undertaken which identified several risk factors for atherosclerosis, with greater attention being paid to individual environmental risk factors and the complexity of its aetiology. Even though psychological distress has been identified as a symptom of cardiac disease in the clinical arena, it has received little attention in this context.

OS was found to be one common factor between CFS and atherosclerosis. Physical or mental stress represents one factor in CFS aetiology; stress results in cellular damage and OS has a significant impact on the endothelium, on molecules such as LDL, on erythrocytes, and consequently on atherogenesis. Compromised cardiovascular systems in many CFS patients, together with the presence of OS in both groups of patients, suggest that there may be common underlying molecular mechanisms in CFS and atherosclerosis.

Biomedical research keeps moving in the direction of investigating diseases at the molecular level and it has a role in furthering knowledge of the nature and treatment of disease. The knowledge gained thereby must be trans- ferred to practice regarding the care of patients. The vast amount of specialized knowledge carries with it the danger that the patient is looked at fragmentarily and that the interconnection between different diseases is underestimated. In this report, by pointing out links between CFS and atherosclerosis, both of which are widespread diseases, emphasis is placed both on holistic treatment approaches and individually tailored strategies in the medical care of patients.

\section{Acknowledgement}

We would like to thank performance sports psychologist Bernard Payet for his valuable guidance and Rajam Csordas for critical reading and stylistic/ linguistic corrections.

\section{Disclosure Statement}

The authors declare that no financial or other conflict of interest exists in relation to the content of this article.

\section{References}

1 World Health Organization: Cardiovascular 11 Jordan KM, Landis DA, Downey MC, Diseases. Fact sheet $\mathrm{N}^{\circ} 317$. Geneva, WHO, 2007.

2 World Health Organization: Cardiovascular diseases. $w w w$.who.int/cardiovascular_diseases/ $e n / ? s=0009$.

3 World Health Organization: Prevention of Cardiovascular Diseases: Guidelines for Assessment and Management of Total Cardiovascular Risk. Geneva, WHO, 2007.

4 Eriksen HR, Ursin H: Subjective health complaints, sensitization, and sustained cognitive activation (stress). J Psychosom Res 2004;56:445-448.

5 Jason LA, Richman JA, Rademaker AW, Jordan KM, Plioplys AV, Taylor RR, McCready W, Huang CF, Plioplys S: A community-based study of chronic fatigue syndrome. Arch Intern Med 1999;159:2129-2137.

6 DeMeirleir K, McGregor N, Van Hoof E: Paediatric Chronic Fatigue Syndrome, ed 1. Bingham, NY, Informa HealthCare, 2007.

7 Prins JB, van der Meer JW, Bleijenberg G: Chronic fatigue syndrome. Lancet 2006; 367:346-355.

8 Steele L, Dobbins JG, Fukuda K, Reyes M, Randall B, Koppelman M, Reeves WC: The epidemiology of chronic fatigue in San Francisco. Am J Med 1998;105:83S-90S.

$\checkmark$ Reyes M, Nisenbaum R, Hoaglin DC, Unger ER, Emmons C, Randall B, Stewart JA, Abbey S, Jones JF, Gantz N, Minden S, Reeves WC: Prevalence and incidence of chronic fatigue syndrome in Wichita, Kansas. Arch Intern Med 2003;163:1530-1536.

$\checkmark 10$ Acheson ED: The clinical syndrome variously called benign myalgic encephalomyelitis, Iceland disease and epidemic neuromyasthenia. Am J Med 1959;26:569-595.
Osterman SL, Thurm AE, Jason LA: Chronic fatigue syndrome in children and adolescents: a review. J Adolesc Health 1998;22:4-18.

12 Chalder T, Goodman R, Wessely S, Hotopf M, Meltzer $\mathrm{H}$ : Epidemiology of chronic fatigue syndrome and self reported myalgic encephalomyelitis in 5-15 year olds: cross sectional study. BMJ 2003;327:654-655.

13 Jones JF, Nisenbaum R, Solomon L, Reyes M, Reeves WC: Chronic fatigue syndrome and other fatiguing illnesses in adolescents: a population-based study. J Adolesc Health 2004;35:34-40.

14 Van Houdenhove B, Egle UT: Fibromyalgia: a stress disorder? Piecing the biopsychosocial puzzle together. Psychother Psychosom 2004;73:267-275

15 Wyller VB: The chronic fatigue syndrome - an update. Acta Neurol Scand Suppl 2007;187:714.

16 Fukuda K, Straus SE, Hickie I, Sharpe MC, Dobbins JG, Komaroff A: The chronic fatigue syndrome: a comprehensive approach to its definition and study. International Chronic Fatigue Syndrome Study Group. Ann Intern Med 1994;121:953-959.

17 Swanink CM, van der Meer JW, Vercoulen JH, Bleijenberg G, Fennis JF, Galama JM: EpsteinBarr virus (EBV) and the chronic fatigue syndrome: normal virus load in blood and normal immunologic reactivity in the EBV regression assay. Clin Infect Dis 1995;20:1390-1392.

18 Schluederberg A, Straus SE, Peterson P, Blumenthal S, Komaroff AL, Spring SB, Landay A, Buchwald D: NIH conference. Chronic fatigue syndrome research. Definition and medical outcome assessment. Ann Intern Med 1992;117:325-331.
9 Salit IE: Precipitating factors for the chronic fatigue syndrome. J Psychiatr Res 1997;31:5965.

20 Bassi N, Amital D, Amital H, Doria A, Shoenfeld Y: Chronic fatigue syndrome: characteristics and possible causes for its pathogenesis. Isr Med Assoc J 2008;10:79-82.

21 Theorell T, Blomkvist V, Lindh G, Evengard B: Critical life events, infections, and symptoms during the year preceding chronic fatigue syndrome (CFS): an examination of CFS patients and subjects with a nonspecific life crisis. Psychosom Med 1999;61:304-310.

22 Ray C, Jefferies S, Weir WR: Life-events and the course of chronic fatigue syndrome. $\mathrm{Br} \mathrm{J}$ Med Psychol 1995;68:323-331.

23 Hoogveld S, Prins J, De Jong L: Personality characteristics and the chronic fatigue syndrome: a review of the literature. Gedragstherapie 2001;34:275-305.

24 Hickie I, Kirk K, Martin N: Unique genetic and environmental determinants of prolonged fatigue: a twin study. Psychol Med 1999;29:259268.

25 Hickie I, Bennett B, Lloyd A, Heath A, Martin N: Complex genetic and environmental relationships between psychological distress, fatigue and immune functioning: a twin study. Psychol Med 1999;29:269-277.

26 Buchwald D, Herrell R, Ashton S, Belcourt M, Schmaling K, Sullivan P, Neale M, Goldberg J: A twin study of chronic fatigue. Psychosom Med 2001;63:936-943.

27 Smith J, Fritz EL, Kerr JR, Cleare AJ, Wessely S, Mattey DL: Association of chronic fatigue syndrome with human leucocyte antigen class II alleles. J Clin Pathol 2005;58:860-863. 
-28 De Becker P, McGregor N, De Meirleir K: Possible triggers and mode of onset of chronic fatigue syndrome. J Chronic Fatigue Syndr 2002;10:3-18.

29 Hatcher S, House A: Life events, difficulties and dilemmas in the onset of chronic fatigue syndrome: a case-control study. Psychol Med 2003;33:1185-1192.

-30 Afari N, Schmaling KB, Herrell R, Hartman S, Goldberg J, Buchwald DS: Coping strategies in twins with chronic fatigue and chronic fatigue syndrome. J Psychosom Res 2000;48:547-554.

-31 Vercoulen JH, Swanink CM, Galama JM, Fennis JF, Jongen PJ, Hommes OR, van der Meer JW, Bleijenberg G: The persistence of fatigue in chronic fatigue syndrome and multiple sclerosis: development of a model J Psychosom Res 1998;45:507-517.

-32 Heijmans MJ: Coping and adaptive outcome in chronic fatigue syndrome: importance of illness cognitions. J Psychosom Res 1998;45: 39-51.

33 Joyce J, Hotopf M, Wessely S: The prognosis of chronic fatigue and chronic fatigue syndrome: a systematic review. QJM 1997;90:223-233.

34 Moss-Morris R, Chalder T: Illness perceptions and levels of disability in patients with chronic fatigue syndrome and rheumatoid arthritis. J Psychosom Res 2003;55:305-308.

35 Moss-Morris R, Petrie K, Weinman J: Functioning in chronic fatigue syndrome: do illness perceptions play a regulatory role? Br J Health Psychol 1996;1:15-25.

>36 Watson NF, Jacobsen C, Goldberg J, Kapur V, Buchwald D: Subjective and objective sleepiness in monozygotic twins discordant for chronic fatigue syndrome. Sleep 2004;27:973977.

-37 Ball N, Buchwald DS, Schmidt D, Goldberg J, Ashton S, Armitage R: Monozygotic twins discordant for chronic fatigue syndrome: objective measures of sleep. J Psychosom Res 2004;56:207-212.

-38 Watson NF, Kapur V, Arguelles LM, Goldberg J, Schmidt DF, Armitage R, Buchwald D: Comparison of subjective and objective measures of insomnia in monozygotic twins discordant for chronic fatigue syndrome. Sleep 2003;26:324328.

\$3 Petrie K, Moss-Morris R, Weinman J: The impact of catastrophic beliefs on functioning in chronic fatigue syndrome. J Psychosom Res 1995;39:31-37.

40 Prins JB, Bos E, Huibers MJ, Servaes P, van der Werf SP, van der Meer JW, Bleijenberg G: Social support and the persistence of complaints in chronic fatigue syndrome. Psychother Psychosom 2004;73:174-182.

41 Brace MJ, Scott Smith M, McCauley E, Sherry DD: Family reinforcement of illness behavior: a comparison of adolescents with chronic fatigue syndrome, juvenile arthritis, and healthy controls. J Dev Behav Pediatr 2000;21:332-339.

42 Butler JA, Chalder T, Wessely S: Causal attributions for somatic sensations in patients with chronic fatigue syndrome and their partners. Psychol Med 2001;31:97-105.

43 Melamed B: Family systems perspective; in Jason LA, Fennell PA, Taylor RR (eds): Handbook of Chronic Fatigue Syndrome. Hoboken, NJ, Wiley \& Sons, 2003.
44 Stanley I, Salmon P, Peters S: Doctors and social epidemics: the problem of persistent unexplained physical symptoms, including chronic fatigue. Br J Gen Pract 2002;52:355356.

45 Page LA, Wessely S: Medically unexplained symptoms: exacerbating factors in the doctorpatient encounter. J R Soc Med 2003;96:223227.

46 Schmaling KB, Smith WR, Buchwald DS: Significant other responses are associated with fatigue and functional status among patients with chronic fatigue syndrome. Psychosom Med 2000;62:444-450.

47 Barsky AJ, Borus JF: Functional somatic syndromes. Ann Intern Med 1999;130:910-921.

48 Kennedy G, Spence VA, McLaren M, Hill A, Underwood C, Belch JJ: Oxidative stress levels are raised in chronic fatigue syndrome and are associated with clinical symptoms. Free Radic Biol Med 2005;39:584-589.

49 Spence VA, Kennedy G, Belch JJ, Hill A, Khan F: Low-grade inflammation and arterial wave reflection in patients with chronic fatigue syndrome. Clin Sci (Lond) 2008;114:561-566.

50 Luger A, Deuster PA, Kyle SB, Gallucci WT, Montgomery LC, Gold PW, Loriaux DL, Chrousos GP: Acute hypothalamic-pituitaryadrenal responses to the stress of treadmill exercise. Physiologic adaptations to physical training. N Engl J Med 1987;316:1309-1315.

51 McEwen BS, Biron CA, Brunson KW, Bulloch K, Chambers WH, Dhabhar FS, Goldfarb RH, Kitson RP, Miller AH, Spencer RL, Weiss JM: The role of adrenocorticoids as modulators of immune function in health and disease: neural, endocrine and immune interactions. Brain Res Brain Res Rev 1997;23:79-133.

52 Clauw DJ, Chrousos GP: Chronic pain and fatigue syndromes: overlapping clinical and neuroendocrine features and potential pathogenic mechanisms. Neuroimmunomodulation 1997;4:134-153.

53 Lariviere WR, Melzack R: The role of corticotropin-releasing factor in pain and analgesia. Pain 2000;84:1-12.

54 Dantzer R: Cytokine-induced sickness behavior: where do we stand? Brain Behav Immun 2001;15:7-24.

55 Chaudhuri A, Behan PO: Fatigue in neurological disorders. Lancet 2004;363:978-988.

56 Pall ML: Elevated, sustained peroxynitrite levels as the cause of chronic fatigue syndrome. Med Hypotheses 2000;54:115-125.

57 Vecchiet J, Cipollone F, Falasca K, Mezzetti A, Pizzigallo E, Bucciarelli T, De Laurentis S, Affaitati G, De Cesare D, Giamberardino MA: Relationship between musculoskeletal symptoms and blood markers of oxidative stress in patients with chronic fatigue syndrome. Neurosci Lett 2003;335:151-154.

58 Richards RS, Roberts TK, McGregor NR, Dunstan RH, Butt HL: Blood parameters indicative of oxidative stress are associated with symptom expression in chronic fatigue syndrome. Redox Rep 2000;51:35-41.

59 Manuel y Keenoy B, Moorkens G, Vertommen J, De Leeuw I: Antioxidant status and lipoprotein peroxidation in chronic fatigue syndrome. Life Sci 2001;68:2037-2049.
60 Logan AC, Wong C: Chronic fatigue syndrome: oxidative stress and dietary modifications. Altern Med Rev 2001;6:450-459.

61 Fulle S, Mecocci P, Fano G, Vecchiet I, Vecchini A, Racciotti D, Cherubini A, Pizzigallo E, Vecchiet L, Senin U, Beal MF: Specific oxidative alterations in vastus lateralis muscle of patients with the diagnosis of chronic fatigue syndrome. Free Radic Biol Med 2000;29:1252-1259.

62 Khalil Z, Liu T, Helme RD: Free radicals contribute to the reduction in peripheral vascular responses and the maintenance of thermal hyperalgesia in rats with chronic constriction injury. Pain 1999;79:31-37.

63 Luo ZD, Cizkova D: The role of nitric oxide in nociception. Curr Rev Pain 2000;4:459-466.

64 Lusis AJ: Atherosclerosis. Nature 2000;407: 233-241.

65 World Health Organization: 5. Population nutrient intake goals for preventing diet-related chronic diseases. www.who.int/nutrition/ topics/5_population_nutrient/en/index.html.

66 American Heart Association: Atherosclerosis. $w w w . a m e r i c a n h e a r t . o r g / p r e s e n t e r . j h t m l ?$ identifier $=228$.

67 Davies MJ, Richardson PD, Woolf N, Katz DR, Mann J: Risk of thrombosis in human atherosclerotic plaques: role of extracellular lipid, macrophage, and smooth muscle cell content. Br Heart J 1993;69:377-381.

68 Lee RT, Libby P: The unstable atheroma. Arterioscler Thromb Vasc Biol 1997;17:1859-1867.

69 Bennett MR: Apoptosis of vascular smooth muscle cells in vascular remodelling and atherosclerotic plaque rupture. Cardiovasc Res 1999;41:361-368.

70 Colles SM, Irwin KC, Chisolm GM: Roles of multiple oxidized LDL lipids in cellular injury: dominance of 7 beta-hydroperoxycholesterol. J Lipid Res 1996;37:2018-2028.

71 Glass CK, Witztum JL: Atherosclerosis. The road ahead. Cell 2001;104:503-516.

72 Galis ZS, Sukhova GK, Lark MW, Libby P: Increased expression of matrix metalloproteinases and matrix degrading activity in vulnerable regions of human atherosclerotic plaques. J Clin Invest 1994;94:2493-2503.

73 Carmeliet P: Proteinases in cardiovascular aneurysms and rupture: targets for therapy? J Clin Invest 2000;105:1519-1520.

74 Navab M, Berliner JA, Watson AD, Hama SY, Territo MC, Lusis AJ, Shih DM, Van Lenten BJ, Frank JS, Demer LL, Edwards PA, Fogelman AM: The Yin and Yang of oxidation in the development of the fatty streak. A review based on the 1994 George Lyman Duff Memorial Lecture. Arterioscler Thromb Vasc Biol 1996; 16:831-842.

75 Cybulsky MI, Gimbrone MA Jr: Endothelial expression of a mononuclear leukocyte adhesion molecule during atherogenesis. Science 1991;251:788-791.

76 Dong ZM, Chapman SM, Brown AA, Frenette PS, Hynes RO, Wagner DD: The combined role of P- and E-selectins in atherosclerosis. J Clin Invest 1998;102:145-152.

77 Collins RG, Velji R, Guevara NV, Hicks MJ, Chan L, Beaudet AL: P-Selectin or intercellular adhesion molecule (ICAM)-1 deficiency substantially protects against atherosclerosis in apolipoprotein E-deficient mice. J Exp Med 2000;191:189-194. 
78 Gerhard GT, Duell PB: Homocysteine and atherosclerosis. Curr Opin Lipidol 1999;10: 417-428.

79 Hofmann MA, Drury S, Fu C, Qu W, Taguchi A, Lu Y, Avila C, Kambham N, Bierhaus A, Nawroth P, Neurath MF, Slattery T, Beach D, McClary J, Nagashima M, Morser J, Stern D, Schmidt AM: RAGE mediates a novel proinflammatory axis: a central cell surface receptor for S100/calgranulin polypeptides. Cell 1999;97:889-901.

-80 Rozanski A, Blumenthal JA, Davidson KW, Saab PG, Kubzansky L: The epidemiology, pathophysiology, and management of psychosocial risk factors in cardiac practice: the emerging field of behavioral cardiology. J Am Coll Cardiol 2005;45:637-651.

81 Rozanski A, Blumenthal JA, Kaplan J: Impact of psychological factors on the pathogenesis of cardiovascular disease and implications for therapy. Circulation 1999;99:2192-2217.

-82 Julkunen J, Salonen R, Kaplan GA, Chesney MA, Salonen JT: Hostility and the progression of carotid atherosclerosis. Psychosom Med 1994;56:519-525

83 Matsumoto Y, Uyama O, Shimizu S, Michishita H, Mori R, Owada T, Sugita M: Do anger and aggression affect carotid atherosclerosis? Stroke 1993;24:983-986.

84 Matthews KA, Owens JF, Kuller LH, SuttonTyrrell K, Jansen-McWilliams L: Are hostility and anxiety associated with carotid atherosclerosis in healthy postmenopausal women? Psychosom Med 1998;60:633-638.

-85 Knox SS, Adelman A, Ellison RC, Arnett DK, Siegmund K, Weidner G, Province MA: Hostility, social support, and carotid artery atherosclerosis in the National Heart, Lung, and Blood Institute Family Heart Study. Am J Cardiol 2000;86:1086-1089.

86 Angerer P, Siebert U, Kothny W, Muhlbauer D, Mudra H, von Schacky C: Impact of social support, cynical hostility and anger expression on progression of coronary atherosclerosis. J Am Coll Cardiol 2000;36:1781-1788.

\$87 Marmot MG, Bosma H, Hemingway $\mathrm{H}$, Brunner E, Stansfeld S: Contribution of job control and other risk factors to social variations in coronary heart disease incidence. Lancet 1997;350:235-239.

88 Lee S, Colditz GA, Berkman LF, Kawachi I: Caregiving and risk of coronary heart disease in U.S. women: a prospective study. Am J Prev Med 2003;24:113-119.

89 Schwartz C, Meisenhelder JB, Ma Y, Reed G: Altruistic social interest behaviors are associated with better mental health. Psychosom Med 2003;65:778-785.

90 Moller P, Wallin H, Knudsen LE: Oxidative stress associated with exercise, psychological stress and life-style factors. Chem Biol Interact 1996;102:17-36.

91 Horn F, Lindenmeier G, Moc I, Grillhösl C, Berghold S, Schneider N (eds): Biochemie des Menschen: das Lehrbuch für das Medizinstudium, ed 2. Stuttgart, Thieme, 2003.

$\checkmark 92$ Cross CE, Halliwell B, Borish ET, Pryor WA, Ames BN, Saul RL, McCord JM, Harman D: Oxygen radicals and human disease. Ann Intern Med 1987;107:526-545.
93 Stocker R, Yamamoto Y, McDonagh AF, Glazer AN, Ames BN: Bilirubin is an antioxidant of possible physiological importance. Science 1987;235:1043-1046.

94 Ames BN: Dietary carcinogens and anticarcinogens. Oxygen radicals and degenerative diseases. Science 1983;221:1256-1264.

$\$ 95$ Goncalves L, Dafre AL, Carobrez SG, Gasparotto OC: A temporal analysis of the relationships between social stress, humoral immune response and glutathionerelated antioxidant defenses. Behav Brain Res 2008;192:226-231.

96 American Heart Association: Heart Attack/ Coronary Heart Disease Risk Assessment. $w w w . a m e r i c a n h e a r t . o r g / p r e s e n t e r . j h t m l$ ? identifier $=3003499$.

-97 Sahin E, Gumuslu S: Alterations in brain antioxidant status, protein oxidation and lipid peroxidation in response to different stress models. Behav Brain Res 2004;155:241-248.

98 Ghizoni DM, Pavanati KC, Arent AM, Machado C, Faria MS, Pinto CM, Gasparotto OC, Gonçalves S, Dafre AL: Alterations in glutathione levels of brain structures caused by acute restraint stress and by nitric oxide synthase inhibition but not by intraspecific agonistic interaction. Behav Brain Res 2006;166:71-77.

99 Kovacs P, Juranek I, Stankovicova T, Svec P: Lipid peroxidation during acute stress. Pharmazie 1996;51:51-53.

100 Kiecolt-Glaser JK, Stephens RE, Lipetz PD, Speicher CE, Glaser R: Distress and DNA repair in human lymphocytes. J Behav Med 1985;8:311-320.

101 Tomei LD, Kiecolt-Glaser JK, Kennedy S, Glaser R: Psychological stress and phorbol ester inhibition of radiation-induced apoptosis in human peripheral blood leukocytes. Psychiatry Res 1990;33:59-71.

102 Haddad JJ, Harb HL: L-gamma-GlutamylL-cysteinyl-glycine (glutathione; GSH) and GSH-related enzymes in the regulation of pro- and anti-inflammatory cytokines: a signaling transcriptional scenario for $\operatorname{redox}(\mathrm{y})$ immunologic sensor(s)? Mol Immunol 2005; 42:987-1014.

103 Sametz W, Prasthofer S, Wintersteiger R, Juan H: Vascular effects of isoprostanes after endothelial damage. Prostaglandins Leukot Essent Fatty Acids 1999;61:369-372.

104 Fontana L, Giagulli C, Minuz P, Lechi A, Laudanna C: 8-Iso-PGF2 alpha induces beta 2 -integrin-mediated rapid adhesion of human polymorphonuclear neutrophils: a link between oxidative stress and ischemia/reperfusion injury. Arterioscler Thromb Vasc Biol 2001;21:55-60.

105 Nordin Fredrikson G, Hedblad B, Berglund G, Nilsson J: Plasma oxidized LDL: a predic tor for acute myocardial infarction? J Intern Med 2003;253:425-429.

106 Costantini F, Pierdomenico SD, De Cesare D, De Remigis P, Bucciarelli T, Bittolo-Bon G, Cazzolato G, Nubile G, Guagnano MT, Sensi S, Cuccurullo F, Mezzetti A: Effect of thyroid function on LDL oxidation. Arterioscler Thromb Vasc Biol 1998;18:732-737.
107 Esterbauer H, Striegl G, Puhl H, Rotheneder $\mathrm{M}$ : Continuous monitoring of in vitro oxidation of human low density lipoprotein. Free Radic Res Commun 1989;6:67-75.

108 Mezzetti A, Guglielmi MD, Pierdomenico SD, Costantini F, Cipollone F, De Cesare D, Bucciarelli T, Ucchino S, Chiarelli F, Cuccurullo F, Romano F: Increased systemic oxidative stress after elective endarterectomy: relation to vascular healing and remodeling. Arterioscler Thromb Vasc Biol 1999;19:26592665.

109 Sen CK: Oxidants and antioxidants in exercise. J Appl Physiol 1995;79:675-686.

110 Nurnberger J, Keflioglu-Scheiber A, Opazo Saez AM, Wenzel RR, Philipp T, Schafers RF: Augmentation index is associated with cardiovascular risk. J Hypertens 2002;20:2407-2414.

111 Covic A, Haydar AA, Bhamra-Ariza P, Gusbeth-Tatomir P, Goldsmith DJ: Aortic pulse wave velocity and arterial wave reflections predict the extent and severity of coronary artery disease in chronic kidney disease patients. J Nephrol 2005;18:388-396.

112 Weber T, Auer J, O’Rourke MF, Kvas E, Lassnig E, Lamm G, Stark N, Rammer M, Eber B: Increased arterial wave reflections predict severe cardiovascular events in patients undergoing percutaneous coronary interventions. Eur Heart J 2005;26:2657-2663.

113 Chirinos JA, Zambrano JP, Chakko S, Veerani A, Schob A, Willens HJ, Perez G, Mendez AJ: Aortic pressure augmentation predicts adverse cardiovascular events in patients with established coronary artery disease. Hypertension 2005;45:980-985.

114 London GM, Blacher J, Pannier B, Guerin AP, Marchais SJ, Safar ME: Arterial wave reflections and survival in end-stage renal failure. Hypertension 2001;38:434-438.

115 Laurent S, Cockcroft J, Van Bortel L, Boutouyrie P, Giannattasio C, Hayoz D, Pannier B, Vlachopoulos C, Wilkinson I, Struijker-Boudier H; European Network for Non-invasive Investigation of Large Arteries: Expert consensus document on arterial stiffness: methodological issues and clinical applications. Eur Heart J 2006;27:2588-2605.

116 Agabiti-Rosei E, Mancia G, O’Rourke MF, Roman MJ, Safar ME, Smulyan H, Wang JG Wilkinson IB, Williams B, Vlachopoulos C: Central blood pressure measurements and antihypertensive therapy: a consensus document. Hypertension 2007;50:154-160.

117 Yasmin, McEniery CM, Wallace S, Mackenzie IS, Cockcroft JR, Wilkinson IB: C-reactive protein is associated with arterial stiffness in apparently healthy individuals. Arterioscler Thromb Vasc Biol 2004;24:969-974.

118 Vlachopoulos C, Dima I, Aznaouridis K, Vasiliadou C, Ioakeimidis N, Aggeli C, Toutouza M, Stefanadis C: Acute systemic inflammation increases arterial stiffness and decreases wave reflections in healthy individuals. Circulation 2005;112:2193-2200.

119 Kaushik N, Fear D, Richards SC, McDermott CR, Nuwaysir EF, Kellam P, Harrison TJ, Wilkinson RJ, Tyrrell DA, Holgate ST, Kerr JR: Gene expression in peripheral blood mononuclear cells from patients with chronic fatigue syndrome. J Clin Pathol 2005;58:826-832. 
120 Richards RS, Roberts TK, Dunstan RH, McGregor NR, Butt HL: Erythrocyte antioxidant systems protect cultured endothelial cells against oxidant damage. Biochem Mol Biol Int 1998;46:857-865

121 Richards RS, Roberts TK, McGregor NR, Dunstan RH, Butt HL: The role of erythrocytes in the inactivation of free radicals. Med Hypotheses 1998;50:363-367.

122 Winterbourn CC, Stern A: Human red cells scavenge extracellular hydrogen peroxide and inhibit formation of hypochlorous acid and hydroxyl radical. J Clin Invest 1987;80:14861491

123 Agar NS, Sadrzadeh SM, Hallaway PE Eaton JW: Erythrocyte catalase. A somatic oxidant defense? J Clin Invest 1986;77:319321.

124 van Asbeck BS, Hoidal J, Vercellotti GM, Schwartz BA, Moldow CF, Jacob HS: Protection against lethal hyperoxia by tracheal insufflation of erythrocytes: role of red cell glutathione. Science 1985;227:756-759.

125 Toth KM, Clifford DP, Berger EM, White CW, Repine JE: Intact human erythrocytes prevent hydrogen peroxide-mediated damage to isolated perfused rat lungs and cultured bovine pulmonary artery endothelial cells. J Clin Invest 1984;74:292-295.

126 Richards RS, Roberts TK, Mathers D, Dunstan RH, McGregor NR, Butt HL: Erythrocyte morphology in rheumatoid arthritis and chronic fatigue syndrome: a preliminary study. J Chronic Fatigue Syndr 2000;6:23-35.

127 Richards RS, Wang L, Jelinek H: Erythrocyte oxidative damage in chronic fatigue syndrome. Arch Med Res 2007;38:94-98.
128 Roberts TK, McGregor NR, Dunstan RH, Donohoe M, Murdoch RN, Hope D, Zhang S, Butt HL, Watkins J, Taylor WG: Immunological and haematological parameters in patients with chronic fatigue syndrome. J Chronic Fatigue Syndr 1998;4:51-65.

129 Moriyama R, Lombardo CR, Workman RF, Low PS: Regulation of linkages between the erythrocyte membrane and its skeleton by 2.3-diphosphoglycerate. J Biol Chem 1993; 268:10990-10996.

130 Chasis JA, Mohandas N: Erythrocyte membrane deformability and stability: two distinct membrane properties that are independently regulated by skeletal protein associations. J Cell Biol 1986;103:343-350.

131 Benesch R, Benesch RE: The effect of organic phosphates from the human erythrocyte on the allosteric properties of hemoglobin. Biochem Biophys Res Commun 1967;26:162167.

132 Chanutin A, Curnish RR: Effect of organic and inorganic phosphates on the oxygen equilibrium of human erythrocytes. Arch Biochem Biophys 1967;121:96-102.

133 Brunauer LS, Moxness MS, Huestis WH: Hydrogen peroxide oxidation induces the transfer of phospholipids from the membrane into the cytosol of human erythrocytes. Biochemistry 1994;33:4527-4532.

134 Barshtein G, Bergelson L, Gratton E, Yedgar S: Human red blood cell shape and volume are changed by physiological levels of hydrostatic pressure. J Basic Clin Physiol Pharmacol 1996;7:321-329.
135 Simpson LO, Murdoch JC, Herbison GP: Red cell shape changes following trigger finger fatigue in subjects with chronic tiredness and healthy controls. N Z Med J 1993;106:104107.

136 Werbach MR: Nutritional strategies for treating chronic fatigue syndrome. Altern Med Rev 2000;5:93-108.

137 Gaab J, Rohleder N, Heitz V, Engert V, Schad T, Schürmeyer TH, Ehlert U: Stressinduced changes in LPS-induced pro-inflammatory cytokine production in chronic fatigue syndrome. Psychoneuroendocrinology 2005;30:188-198.

138 Yoshiuchi K, Quigley KS, Ohashi K, Yamamoto Y, Natelson BH: Use of timefrequency analysis to investigate temporal patterns of cardiac autonomic response during head-up tilt in chronic fatigue syndrome. Auton Neurosci 2004;113:55-62.

139 De Becker P, Roeykens J, Reynders M, McGregor N, De Meirleir K: Exercise capacity in chronic fatigue syndrome. Arch Intern Med 2000;160:3270-3277.

140 Stewart JM: Autonomic nervous system dysfunction in adolescents with postural orthostatic tachycardia syndrome and chronic fatigue syndrome is characterized by attenuated vagal baroreflex and potentiated sympathetic vasomotion. Pediatr Res 2000;48:218-226.

141 US Centers for Disease Control and Prevention: The Revised Case Definition (abridged version). $h t t p: / / w w w . c d c . g o v / c f s / g e n e r a l / c a s e$ definition/index.html.

142 Steinhubl SR: Why have antioxidants failed in clinical trials? Am J Cardiol 2008;101:14D19D. 